\title{
OPTIMASI PENGAWASAN OLEH OTORITAS JASA KEUANGAN DI BIDANG PASAR MODAL MENURUT HUKUM POSITIF DI INDONESIA
}

\author{
I GUSTI AGUNG WISUDAWAN ${ }^{1)}$, BUDI SUTRISNO ${ }^{2)}$, DIMAN ADE MULADA ${ }^{3)}$
}

\author{
Fakultas Hukum Universitas Mataram
}

email: agung.wisudawan@gmail.com

\begin{abstract}
ABSTRAK
Perkembangan pasar modal di Indonesia mengalami peningkatan dari waktu ke waktu tetapi perkembangan ini bukan berarti tanpa hambatan. Hambatan yang sering muncul adalah terjadinya berbagai praktik kecurangan di pasar modal yang melibatkan subjek hukum di dalam pasar modal itu sendiri. Oleh karena itu diperlukan optimasi pengawasan oleh OJK di bidang Pasar Modal dalam rangka meminimalisir praktek kecurangan tersebut. Adapun jenis penelitian yang digunakan dalam penelitian ini adalah Penelitian Normatif dengan pendekatan Perundang-undangan (Statute Approach), Pendekatan Konseptual (Coceptual Approach), Pendekatan Kasus (Case Approach) dan Pendekatan Analisis (Analitical Approach). Penelitian ini juga menggunakan Bahan Hukum yang terdiri atas Bahan Hukum Primer yaitu bahan hukum berupa Undang-undang No 8 Tahun 1995 tentang Pasar Modal dan Undang -undang serta peraturan OJK, Bahan Hukum Skunder yaitu literatur yang berkaitan dengan permasalahan yang diangkat dalam penelitian ini dan Bahan Hukum Tersier terdiri atas kamus hukum dan ensiklopedi. Teknik pengumpulan bahan hukum yang dipergunakan dalam penelitian ini adalah Studi Dokumentasi dengan Analisis Bahan Hukum yaitu Analisis Deskriftif Kualitatif.

Hasil Kajian penelitian ini yaitu Optimasi Pengawasan Oleh Otoritas Jasa Keuangan Di bidang Pasar Modal Menurut hukum Positif di Indonesia yaitu Mengadakan revisi terhadap Undang-undang No 8 Tahun 1995 Tentang Pasar Modal. Melakukan revisi terhadap Undang-undang Nomor 21 Tahun 2011 Tentang Otoritas Jasa Keuangan. Adapun mekanisme pengawasan yang dilakukan oleh OJK adalah menggunakan sistem supervisory tools dan supervisory action meliputi berbagai pemeriksaan seperti transasksi efek, kepatuhan lembaga efek, kepatuhan pengelolaan investasi, kepatuhan emiten dan kepatuhan profesi dan lembaga penunjang.
\end{abstract}

Kata Kunci: Optimasi, Pengawasan, Otoritas Jasa Keuangan

\section{ABSTRACT}

The development of the capital market in Indonesia has increased from time to time but this development is not without obstacles. The obstacle that often arises is the occurrence of fraudulent practices in the capital market involving legal subjects in the capital market itself. Therefore, it is necessary to optimize supervision by the OJK in the Capital Market sector to minimize this fraudulent practice. The type of research used in this research is Normative Research with a statutory approach (Statute Approach), Conceptual Approach (Conceptual Approach), Case Approach (Case Approach), and Analysis Approach (Analytical Approach). This study also uses legal materials which consist of primary legal materials, namely legal materials in the form of Law No. 8 of 1995 concerning the Capital Market and OJK laws and regulations, secondary legal materials, namely literature related to the issues raised in this study and materials. Tertiary Law consists of a legal dictionary and encyclopedia. Legal material collection techniques used in this research is a Documentation Study with Legal Material Analysis, namely Qualitative Descriptive Analysis.

The results of this study are Optimization of Supervision by the Financial Services Authority in the Capital Market according to positive law in Indonesia, namely Revising Law No. 8 of 1995 concerning Capital Markets. Revised Law Number 21 the Year 2011 concerning the Financial Services Authority. The supervisory mechanism carried out by the OJK is to use a system of supervisory tools and supervisory action covering various checks such as securities transactions, securities agency compliance, investment management compliance, issuer compliance, and professional and supporting institutions compliance.

Keywords: Optimization, Supervision, Financial Services Authority 


\section{PENDAHULUAN}

Perkembangan pasar modal di Indonesia mengalami peningkatan dari waktu ke waktu tetapi perkembangan ini bukan berarti tanpa hambatan. Hambatan yang sering muncul adalah terjadinya berbagai praktik kecurangan di pasar modal yang melibatkan subjek hukum di dalam pasar modal itu sendiri yang tentunya paham seluk beluk kegiatan perdagangan di pasar modal seperti penggunaan saham nominee, praktek insider trading, permainan harga saham, manipulasi harga saham, pengaturan indeks saham, sarana money politics, sarana pencucian uang, praktek late trading, paraktek market timing dan menyamakan produk reksadana seperti deposito. Oleh karena itu diperlukan pengawasan yang maksimal oleh Otoritas Jasa Keuangan. Otoritas Jasa Keuangan merupakan lembaga yang sifatnya idependent yang dibentuk berdasarkan Undang-undang No 21 Tahun 2011, lembaga ini berperan sebagai lembaga pembina, pengatur sekaligus menegakkan aturan hukum di Pasar Modal dalam rangka memberikan perlindungan hukum kepada investor sekaligus mencipatakan Pasar Modal yang tertib, efisien, dan profesional.

Selanjutnya dalam rangka memberikan kepastian, keadilan dan perlindungan hukum bagi investor, maka diperlukan optimasi dalam bentuk model pengawasan oleh Otoritas Jasa Keuangan (OJK) guna memaksimalkan pengawasan dan meminimalisir praktek kecurangan termasuk melakukan reformasi regulasi di bidang pasar modal. Berdasarkan hal tersebut di atas Penulis tertarik untuk meneliti tentang Optimasi Pengawasan Oleh Otoritas Jasa Keuangan di Bidang Pasar Modal Menurut Hukum Positif di Indonesia.

\section{Rumusan Masalah}

Berdasarkan latar belakang sebagaimana diuraikan di atas, maka pokok permasalahan yang akan menjadi kajian dari penelitian ini dapat dirumuskan sebagai berikut:

1. Bagaimana optimasi pengawasan oleh otoritas jasa keuangan di bidang Pasar Modal menurut hukum positif di Indonesia?

2. Bagaimana mekanisme pengawasan dan pengenaan sanksi oleh otoritas jasa keuangan terhadap praktek kecurangan di Pasar Modal menurut hukum positif di Indonesia?

\section{Tujuan dan Manfaat Penelitian}

Penelitian ini sangat penting untuk dilakukan dengan harapan bahwa hasil yang ingin dicapai yaitu mampu menghasilkan analisis yang mendalam dan komperhensif tentang optimasi pengawasan oleh otoritas jasa keuangan di bidang pasar modal menurut hukum positif di Indonesia, dalam rangka mewujudkan pasar modal yang memberikan kepastian hukum dan berkeadilan hukum serta memiliki sifat keberlanjutan. Hasil penelitian diharapkan dapat dimanfaatkan mengembangkan konsep-konsep hukum dalam Hukum Pasar Modal terutama yang berkaitan dengan optimasi pengawasan oleh Otoritas Jasa Keuangan di Bidang Pasar Modal Menurut Hukum Positif di Indonesia dan secara praktis diharapkan dapat memberikan hasil yang sangat berguna bagi mahasiswa, praktisi hukum dan konsultan hukum serta OJK .

\section{METODE PENELITIAN}

Adapun jenis penelitian ini adalah penelitian Normatif yaitu penelitian yang mengkaji dan menganalisis tentang peraturan perundang-undangan maupun peraturan lain yang ada hubungannya dengan permasalahan di atas. Dalam melakukan penelitian normatif ini menggunakan peraturan perundangundangan, teori hukum, pendapat hukum dari para ahli hukum terutama yang berkaitan dengan optimasi Pengawasan yang dilakukan OJK di Bidang Pasar Modal Menurut Hukum Positif di Indonesia. Adapun metode pendekatan yang digunakan dalam penelitian ini adalah Pendekatan Perundang-undangan (Statute Approach) yaitu pendekatan yang dilakukan dengan melihat semua peraturan perundang-undangan yang erat kaitannya dengan permasalahan yang akan diteliti. Hal ini dilakukan karena peraturan perundanganundangan merupakan titik fokus dari penelitian ini, pendekatan konseptual (Conceptual Aprroach) yaitu pendekatan yang merujuk dari pandangan-pandangan dan doktrin-doktrin di dalam ilmu hukum. Dengan mempelajari pandangan-pandangan dan doktrin-doktrin tersebut dihrapkan dapat menemukan ide-ide baru yang eksploratif mengenai pengertian-pengertian hukum, asas-asas hukum dan konsep-konsep dalam hukum.

Adapun jenis dan sumber bahan hukum yang digunakan dalam penelitian ini adalah sebagai berikut :Bahan Hukum Primer yaitu bahan hukum yang berupa peraturan perundang-undangan yang berlaku serta ada kaitannya dengan permasalahan yang akan dibahas yaitu Undang-undang No 8 Tahun 1995 Tentang Pasar Modal, Undang-undang No 21 Tahun 2011 Tentang Otoritas Jasa Keuangan, Bahan Hukum Sekunder 
yaitu bahan hukum yang menjelaskan bahan hukum primer, yakni berupa rancangan perundang-undangan, hasil penelitian, buku-buku teks, seminar, diskusi dan berita internet, dan Bahan Hukum Tersier yaitu bahan hukum yang memberikan informasi tentang bahan hukum primer dan sekunder antara lain kamus hukum dan ensiklopedia yang dapat membantu memahami dan menganalisis masalah penelitian.

Adapun teknik pengumpulan bahan hukum yang penulis gunakan dalam penelitian ini adalah studi dokumentasi atau bahan pustaka yaitu dengan cara mengumpulkan bahan hukum yang dilakukan dengan jalan membaca dan mengkaji berbagai literatur-literatur dan bahan-bahan lainnya guna menemukan jawaban atau solusi terhadap masalah yang diteliti, bahan hukum yang telah terkumpul dalam penelitian ini kemudian dianalisis dengan mengunakan metode analisis kualitatif adalah analisis data yang diperoleh dari penelitian kepustakaan kemudian menguraikannya bermula dari hal-hal yang bersifat umum kepada hal-hal yang bersifat khusus dan analisis deskriptif adalah analisis yang bertujuan untuk membahas bahan hukum yang telah dikumpulkan kemudian menguraikannya sesuai dengan pokok permasalahannya baik dalam bentuk teoritis maupun praktis.

\section{HASIL DAN PEMBAHASAN}

\section{Optimasi Pengawasan Oleh Otoritas Jasa Keuangan Di bidang Pasar Modal Menurut hukum Positif di Indonesia}

Otoritas Jasa Keuangan merupakan lembaga yang independen yang mempunyai fungsi, tugas, dan wewenang pengaturan, pengawasan, pemeriksaan, dan penyidikan tidak hanya pada lembaga keuangan tetapi juga pasar modal. Adapun mengenai latar belakang berdirinya Otoritas Jasa Keuangan yang selanjutnya disebut sebagai OJK yaitu lembaga Negara yang dibentuk berdasarkan Undang-undang Nomor 21 Tahun 2011 yang berfungsi menyelenggarakan sistem pengaturan dan pengawasan yang terintegrasi terhadap keseluruhan kegiatan di dalam sektor jasa keuangan baik di sektor perbankan, pasar modal, dan sektor jasa keuangan non-bank seperti Asuransi, Dana Pensiun, Lembaga Pembiayaan, dan Lembaga Jasa Keuangan lainnya.

Tujuan dari pembentukan OJK telah diatur di dalam Pasal 4 Undang-undang Nomor 21 Tahun 2011 Tentang OJK yang intinya agar keseluruhan kegiatan di dalam sektor jasa keuangan terselenggara secara teratur, adil, transparan, akuntabel dan mampu mewujudkan sistem keuangan yang tumbuh secara berkelanjutan dan stabil, serta mampu melindungi kepentingan konsumen maupun masyarakat (investorpenyusun). Hal ini tentunya telah sejalan juga dengan tujuan pembentukan Undang-undang No 8 Tahun 1995 Tentang Pasar Modal yaitu untuk melindungi kepentingan investor yang akhirnya akan meningkatkan daya saing perekonomian baik nasional maupun global. OJK juga harus mampu melindungi kepentingan nasional bangsa Indonesia seperti penigkatan sumber daya manusia, pengelolaan, pengendalian, dan kepemilikan di sektor jasa keuangan dengan memperhatikan aspek positif globalisasi. OJK dibentuk dengan menerapkan prinsip-prinsip tata kelola yang baik, yang meliputi independensi, akuntabilitas, pertanggungjawaban, transparansi, dan kewajaran (fairness).

Fungsi OJK yaitu menyelenggarakan sistem pengaturan dan pengawasan yang terintegrasi terhadap keseluruhan kegiatan di sektor jasa keuangan. Tujuan dan fungsi sebagaimana yang telah diuraikan di atas memang sangat bagus, tetapi dalam implementasinya di lapangan belum optimal dilakukan oleh Otoritas Jasa Keuangan, hal ini terjadi karena OJK terlihat bersifat pasif artinya bahwa OJK hanya menerima laporan dari Lembaga Keuangan atau Subjek Hukum di Pasar Modal, seharusnya secara ideal OJK dapat secara aktif melakukan pengawasan dalam rangka melindungi kepentingan konsumen atau investor yang rentan dengan dirugikan oleh oknum subjek hukum di bidang Pasar Modal. Oleh karena itu ke depan diperlukan optimasi pengawasan oleh Otoritas Jasa Keuangan sehingga dapat memberikan kepastian dan keadilan hukum bagi para investor, sebab titik tekan yang paling utama bidang pasar modal di Pasar Modal adalah perlindungan hukum bagi investor.

Strategi yang paling utama khususnya yang akan diterapkan di bidang pasar modal yaitu mengintegrasikan pengaturan dan pengawasan lembaga keuangan, Meningkatkan kapasitas pengaturan dan pengawasan dan Membangun sistem perlindungan konsumen keuangan yang terintegrasi dan melaksanakan edukasi dan sosialisasi yang masif dan komprehensif. Optimasi khususnya dalam pengawasan merupakan titik tekan yang paling krusial di bidang Pasar Modal dalam rangka memberikan perlindungan hukum bagi investor demi mewujudkan Pasar Modal yang tertib, teratur dan efisien. Optimasi mengandung pengertian suatu proses untuk mencapai hasil yang ideal atau nilai efektif yang dapat dicapai. Optimasi dapat diartikan sebagai suatu bentuk mengoptimalkan sesuatu hal yang sudah ada, ataupun merancang dan membuat sesusatu secara optimal.

Terdapat beberapa teori hukum yang mendukung optimasi pengawasan yang dilakukan oleh OJK yaitu Teori Hukum Pembangunan, Teori Negara Hukum, Teori Sistem, Teori Utilitis, Teori Hukum Progresif 
dan Teori Hukum Responsif. Selanjutnya optimasi pengawasan terhadap Pasar Modal di Indonesia dapat dilakukan dengan cara :

1. Mengadakan revisi terhadap Undang-undang No 8 Tahun 1995 Tentang Pasar Modal yang di dalamnya lebih menekankan peran OJK sebagai lembaga pengatur, pembina, pengawas dan penegak hukum di bidang Pasar Modal.

2. Melakukan revisi terhadap Undang-undang Nomor 21 Tahun 2011 Tentang Otoritas Jasa Keuangan yang di dalamnya lebih menekankan pengawasan yang bersifat aktif dan bukan pasif.

3. Tidak lagi menggunakan aturan-aturan lama yang masih berkaitan dengan Bapepam-LK.

4. Melakukan pengawasan berbasis sistem yaitu melibatkan seluruh pihak yang terlibat di pasar modal termasuk pihak Bursa Efek Indonesia, organisasi profesi penunjang di pasar modal salah satunya seperi HKHPM (Himpunan Konsultan Hukum Pasar Modal) dan pemerintah.

5. Membuat peraturan OJK tersendiri dalam hal pengawasan terhadap pelaku di Pasar Modal .

6. Mengadakan evaluasi secara berkala terhadap progress yang telah dicapai, dan menginventarisir segala hambatan dan tantangan yang dihadapi pada waktu menjalankan tugas pengawasan di Pasar Modal.

7. Memperkuat sanksi hukum dalam setiap aturan yang dibuat oleh OJK.

Dalam rangka optimasi pengawasan yang dilakukan oleh OJK, maka perlu diterapkan Prinsip Keterbukaan Informasi dengan tujuan agar semua pihak yang terlibat di Pasar Modal dapat mengetahui hasil pengawasan yang dilakukan dan menindak pihak-pihak yang terindikasi melakukan perbuatan melawan hukum di bidang Pasar Modal yang telah merugikan investor. Pengawasan yang dilakukan oleh OJK merupakan implementasi dari Prinsip Keadilan khususnya bagi investor yang akan berinvestasi di bidang Pasar Modal. Keadilan merupakan keadaan kebenaran ideal secara moral mengenai sesuatu hal, baik menyangkut benda atau orang. Menurut Aristoteles menyatakan bahwa "tujuan dari hukum adalah sematamata untuk mewujudkan keadilan”. (Rahman Syamsuddin:2019:9)

\section{Mekanisme Pengawasan dan Pengenaan Sanksi Oleh Otoritas Jasa Keuangan Terhadap Praktek Kecurangan di Pasar Modal Menurut Hukum Positif di Indonesia.}

Dengan adanya Undang-undang No 21 Tahun 2011 Tentang OJK maka peran BAPEPAM telah digantikan oleh OJK dalam hal pembinaan, pengaturan dan pengawasan di bidang Pasar Modal. Adapun peralihan tersebut meliputi :

1. Memberi

a. Izin usaha kepada bursa efek, lembaga kliring dan penjaminan, lembaga penyimpanan dan penyelesaian, reksa dana, perusahaan efek, penasihat investasi, dan biro administrasi efek;

b. Izin orang perseorangan bagi wakil penjamin emisi efek, wakil perantara pedagang efek, dan wakil manager investasi.

2. Mewajibkan pendaftaran profesi penunjang pasar modal dan wali amanat.

3. Menetapkan persyaratan dan tata cara pencalonan dan memberhentikan untuk sementara waktu komisaris dan atau direktur serta menunjuk sementara manajemen bursa efek, lembaga kliring dan penjaminan, serta lembaga penyimpanan dan penyelesaian sampai dengan dipilihnya komisaris dan atau direktur yang baru.

4. Menetapkan persyaratan dan tata cara pernyataan pendaftaran serta menyatakan, menunda, atau membatalkan efektifnya pernyataan pendaftaran.

5. Mengadakan pemeriksaan dan penyidikan terhadap setiap pihak dalam hal terjadi peristiwa yang diduga merupakan pelanggaran terhadap undang-undang pasar modal dan peraturan pelaksanaannya.

6. Mewajibkan setiap pihak untuk:

a. Menghentikan atau memperbaiki iklan atau promosi yang berhubungan dengan kegiatan pasar modal, atau

b. Mengambil langkah-langkah yang diperlukan untuk mengatasi akibat yang timbul dari iklan atau promosi tersebut.

7. Melakukan pemeriksaan terhadap:

a. Setiap emiten atau perusahaan publik yang telah atau diwajibkan menyampaikan pernyataan pendaftaran kepada Bapepam,

b. Pihak yang dipersyaratkan untuk memiliki izin usaha, izin orang perseorangan, persetujuan, atau pendaftaran profesi berdasarkan undang-undang pasar modal.

8. Menunjuk pihak lain untuk melakukan pemeriksaan tertentu dalam rangka pelaksanaan wewenang pengawasan sebagaimana terdapat dalam angka 7.

9. Mengumumkan hasil pemeriksaan.

10. Membekukan atau membatalkan pencatatan suatu efek pada bursa efek atau menghentikan transaksi bursa atas efek tertentu untuk jangka waktu tertentu guna melindungi kepentingan pemodal. 
11. Menghentikan kegiatan bursa efek untuk jangka waktu tertentu dalam keadaan darurat.

12. Mengajukan keberatan yang diajukan oleh pihak yang dikenakan sanksi oleh bursa efek, lembaga kliring dan penjaminan, lembaga penyimpanan dan penyelesaian serta memberikan keputusan membatalkan atau menguatkan pengenaan sanksi dimaksud.

13. Menetapkan biaya perizinan, persetujuan, pendaftaran, pemeriksaan dan penelitian serta biaya lain dalam rangka kegiatan pasar modal.

14. Melakukan tindakan yang diperlukan untuk mencegah kerugian masyarakat sebagai akibat atas pelanggaran di bidang pasar modal.

15. Memberikan penjelasan lebih lanjut yang bersifat teknis atas undang-undang pasar modal atau peraturan pelaksanaannya.

16. Menetapkan instrumen lain sebagai efek selain yang telah ditentukan dalam Pasal 1-Pasal 5, dan

17. Melakukan hal-hal lain yang diperkenankan berdasarkan undang-undang pasar modal

Dalam perkembangannya mekanisme pengawasan yang dilakukan oleh OJK dari tahun 2016 sampai dengan tahun 2019 sebagaimana yang dikutip dari https://native.kontan.co.id/news/ojk-perketatpengawasan-pasar-modal-tingkatkan-kepercayaan-investor memang bertahap yaitu: Bentuk pengawasan yang dilakukan oleh OJK seperti supervisory tools dan supervisory action meliputi berbagai pemeriksaan seperti transasksi efek, kepatuhan lembaga efek, kepatuhan pengelolaan investasi, kepatuhan emiten dan kepatuhan profesi dan lembaga penunjang hal ini telah dilakukan sejak tahun 2019 dalam rangka menjaga kepercayaan investor yang berinvestasi di Pasar Modal.

Selanjutnya OJK juga mendapatkan hasil yang maksimal atas penggunaan metode pengawasan ini seperti yang dilansir https://native.kontan.co.id/news/ojk-perketat-pengawasan-pasar-modal-tingkatkankepercayaan-investor yang menyatakan bahwa : Alhasil berbagai pelanggaran ditemukan dari aksi pengawasan ini seperti perdagangan semu, manipulasi harga, fixed return reksa dana, pemasar reksa dana tanpa izin, pelanggaran RUPS/RUPSLB dan lain-lainnya. Dari berbagai pelanggaran tersebut, OJK memberikan sanksi dan tindaklanjut pengawasan seperti melakukan pemeriksaan investigasi terhadap 17 saham, 8 ebus dan 3 warran serta mensuspen perdagangan 5 saham. OJK juga memberikan sanksi penghentian kegiatan usaha terhadap 10 perusahaan efek, teguran tertulis kepada 3 perusahaan efek dan pembekuan izin 1 Wakil Perantara Perdagangan Efek (WPPE). Selain itu dikeluarkan perintah untuk melakukan tindakan tertentu kepada 36 Manajer Investasi, dan menutup 6 produk Reksa Dana fixed return serta membekukan satu Wakil Manajer Investasi. OJK terus melanjutkan supervisory action untuk memeriksa kepatuhan pelaku pasar modal pada 2020, yang hingga Juni telah dilakukan pemeriksaan dan penelaahan transaksi efek terhadap 2 Efek Bersifat Utang dan Sukuk, pemeriksaan kepatuhan Lembaga Efek terhadap 12 Perusahaan Efek dan 1 SRO, pemeriksaan kepatuhan kepada 5 emiten serta pemeriksaan kepatuhan Pengelolaan Investasi terhadap 9 manajer investasi, 2 agen penjual efek Reksa Dana, dan 1 Bank Kustodian.

Hal ini dapat dikatakan maksimal tetapi ke depan tentunya OJK harus lebih aktif melakukan pengawasan yng terintegrasi agar dapat mengungkap pelanggaran di bidang Pasar Modal yang lebih banyak lagi guna menciptakan Pasar Modal yang bersih, efektif, tertib dan efisien. Tujuan dari berbagai pengawasan yang dilakukan oleh OJK saat ini adalah untuk mempercepat reformasi di bidang Pasar Modal sehingga dapat meningkatkan kepercayaan investor untuk berinvestasi di Pasar Modal. Selain itu Upaya yang harus dilakukan oleh OJK dalam melakukan reformasi di Bidang Pasar Modal seperti mempercepat proses perizinan, peningkatan standar, penguatan pengawasan, dan penegakan aturan hukum sesuai dengan Undang-undang Nomor 8 Tahun 1995 Tentang Pasar Modal.

Berbagai pelanggaran dan kecurangan yang kerap kali terjadi di Pasar Modal diantaranya yaitu : Penggunaan Saham Nominee, Insider Trading, Permainan Harga Saham, Pengaturan Indeks Saham, Sarana Money Politics, Sarana Pencusian Uang, Praktek Late Trading, Praktek Market Timing dan Menyamakan Produk Reksadana Seperti Deposito. Jika berbagai kasus pelanggaran di atas terus dibiarkan begitu saja, maka akan berimplikasi pada berkurangnya kepercayaan investor untuk berinvestasi di Pasar Modal.

Selanjutnya menurut Kepala Deputi Pengawasan Pasar Modal 1A OJK Luthfy Zain Fuady sebagaimana yang dikutip dari https://www.cnbcindonesia.com/market/20201022130718-17-196306/ojkbongkar-para-bandit-pasar-modal-modus-operandinya menyatakan bahwa : Terdapat empat lembaga yang kerap melakukan pelanggaran di pasar modal dengan berbagai modus. Empat lembaga tersebut yaitu perusahaan efek, manajer investasi, emiten dan profesi/lembaga penunjang. Modus pelanggaran yang dilakukan perusahaan efek, seperti perdagangan semu yang menciptakan harga yang tidak sepenuhnya disebabkan karena adanya permintaan jual dan beli efek di pasar. Hal ini menimbulkan adanya manipulasi harga saham. Bentuk kejahatan lainnya yang juga sering terjadi adalah aktivitas transaksi oleh pegawai yang dilakukan tanpa izin dan kegiatan arranger emisi efek yang dilakukan tanpa izin. Pelanggaran yang dilakukan oleh Manajer Investasi yaitu bentuk komposisi dan valuasi efek yang dijadikan portofolio reksa dana. 
Lainnya seperti adanyacross trading,afiliasi dan benturan kepentingan yang dilakukan oleh manajer investasi. miten juga kerap melakukan pelanggaran aturan pasar modal. Modusnya tidak memberikandisclosureyang sesuai dengan aturan seperti penyampaian keterbukaan informasi dan situs web resmi perusahaan. pelanggaran yang dilakukan profesi/lembaga penunjang biasanya dalam bentuk tidak memenuhi ketentuan OJK dan kode etik profesi yang berlaku. Selain itu, beberapa kali juga ditemukan adanya penandatanganan kontrak saat izinnya telah dicabut atau dibekukan.

Jika berbagai kasus pelanggaran di atas terus dibiarkan begitu saja, maka akan berimplikasi pada berkurangnya kepercayaan investor untuk berinvestasi di Pasar Modal. Oleh karena itu peranan OJK dalam pengawasan dan penegakan hukum sangat diperlukan guna meminimalisasi pelanggaran atau kecurangan sebagaimana yang telah diurakan di atas. Mengenai sanksi yang dapat dikenakan terhadap praktek pelanggaran dan kecurangan yang terjadi di Pasar Modal adalah Sanksi Administratif sebagaimana yang terdapat di dalam Pasal 102 Undang-undang Nomor 8 Tahun 1995 Tentang Pasar Modal, Sanksi Pidana yang diatur di dalam Pasal 103 sampai Pasal 110 Undang-undang Nomor 8 Tahun 1995 Tentang Pasar Modal dan KUHP jika berkaitandengan penipuan (Pasal 378 KUHP) dan penggelapan (Pasal 372 KUHP) dan Sanksi Perdata yaitu ganti kerugian sebagaimana yang dimaksud di dalam Pasal 1365 KUH Perdata yang pada intinya menyatakan bahwa: "Tiap perbuatan melawan hukum yang membawa kerugian kepada orang lain, mewajibkan orang karena salahnya menerbitkan kerugian itu, mengganti kerugian tersebut".

Dalam rangka pengawasan yang dilakukan oleh OJK tentunya dibantu oleh pihak Bursa Efek Indonesia, berdasarkan https://market.bisnis.com/read/20190815/7/1136922/tindak-tegas-pelanggaran-dipasar-modal-pengamat-apresiasi-ojk-dan-bei menyatakan bahwa : Per 9 Agustus 2019, OJK telah melakukan 61 pemeriksaan terhadap pelaku industri pasar modal dan mengenakan 275 sanksi administratif berupa denda, 1 sanksi pencabutan izin, 102 sanksi peringatan tertulis, 3 sanksi pembekuan izin, dan 4 perintah tertulis. Terbaru adalah pemberian sanksi denda kepada PT Hanson International Tbk. terkait dengan pelanggaran dalam penyajian laporan keuangan tahun buku 2016.Dalam kasus itu, emiten bersandi saham MYRX dan dua direksinya dikenakan sanksi senilai total Rp5,6 miliar oleh OJK karena terbukti melakukan pelanggaran menyangkut penjualan kavling siap bangun dengan nilai kotor Rp732 miliar.Sherly Jokom sebagai akuntan dari rekan pada Kantor Akuntan Publik Purwantono Sungkoro dan Surja, anggota Ernst and Young Global Limited, juga dikenakan sanksi administratif berupa pembekuan STTD selama 1 tahun.Sebelumnya, denda lebih dari Rp300 juta dilayangkan kepada PT Garuda Indonesia (Persero) Tbk. serta direksi dan komisaris yang menandatangani laporan keuangan tahunan 2018 yang terbukti memuat pelanggaran.Dalam kasus ini, Kasner Sirumapea selaku akuntan dan rekan pada KAP Tanubrata, Sutanto, Fahmi, Bambang \& Rekan (Member of BDO International Limited) juga dibekukan izin STTD-nya selama setahun.Tak hanya emiten dan Akuntan Publik, baru-baru ini PT BNI Sekuritas pun kena teguran dari Bursa Efek Indonesia dan harus membayar denda karena menyajikan laporan modal kerja bersih disesuaikan (MKBD) secara tidak akurat.Berdasarkan pengumuman yang disampaikan lewat laman resmi BEI, bursa memberikan sanksi peringatan tertulis dan denda sejumlah Rp250 juta kepada anak usaha PT Bank Negara Indonesia (Persero) Tbk. (BBNI) tersebut.

Hal ini menunjukkan kesungguhan dan komitmen dari Otoritas Jasa Keuangan bersama Bursa Efek Indonesia dalam rangka melaksanakan tugas, dan fungsinya serta meciptakan reformasi pasar modal dan menjadikan pasar modal menjadi tertib, efisien dan profesional guna mendukung pembangunan ekonomi nasional Indonesia. Selain itu tindakan yang telah dilakukan oleh pihak OJK tersebut merupakan bagian dari penegakan hukum. Menurut Jimly Asshiddiqie sebagaimana yang dimuat di dalam https://blogmhariyanto.blogspot.com/2009/09/penegakan-hukum-pelaku-tindak-pidana.html menyatakan bahwa : "Penegakan hukum adalah proses dilakukannya upaya untuk tegaknya atau berfungsinya normanorma hukum secara nyata sebagai pedoman perilaku dalam lalu lintas atau hubungan-hubungan hukum dalam kehidupan bermasyarakat dan bernegara". Tentunya dalam penegakan hukum tersebut harus memperhatikan kepastian hukum , keadilan dan kemanfaatan. Pengawasan yang dilakukan oleh OJK dapat pula diartikan sebagai bentuk perlindungan hukum yang diberikan kepada para investor di Pasar Modal. Perlindungan hukum merupakan serangkaian upaya yang dilakukan oleh seseorang atau sekelompok orang untuk mengamankan haknya dari orang yang akan merugiakan haknya tersebut. Perlindungan hukum yang terimplementasi dalam kegiatan pengawasan tersebut bersifat preventif yang konstruktif untuk perbaikan baik sistem maupun kinerja berbagai pihak di dalam Pasar Modal Indonesia.

\section{PENUTUP}

\section{Simpulan}

Optimasi Pengawasan Oleh Otoritas Jasa Keuangan Di bidang Pasar Modal Menurut hukum Positif di Indonesia yaitu Mengadakan revisi terhadap Undang-undang No 8 Tahun 1995 Tentang Pasar Modal yang di 
dalamnya lebih menekankan peran OJK sebagai lembaga pengatur, pembina, pengawas dan penegak hukum di bidang Pasar Modal, Melakukan revisi terhadap Undang-undang Nomor 21 Tahun 2011 Tentang Otoritas Jasa Keuangan yang di dalamnya lebih menekankan pengawasan yang bersifat aktif dan bukan pasif, Tidak lagi menggunakan aturan-aturan lama yang masih berkaitan dengan Bapepam-LK, Melakukan pengawasan berbasis sistem dan terintegrasi serta menaggunakan teknologi yaitu melibatkan seluruh pihak yang terlibat di pasar modal dan organisasi profesi penunjang pasar modal seperti HKHPM serta pemerintah, Membuat peraturan OJK tersendiri dalam hal pengawasan terhadap pelaku di Pasar Modal, Mengadakan evaluasi secara berkala terhadap progress yang telah dicapai, dan menginventarisir segala hambatan dan tantangan yang dihadapi pada waktu menjalankan tugas pengawasan di Pasar Modal, Memperkuat sanksi hukum dalam setiap aturan yang dibuat oleh OJK. Dalam rangka mendukung optimasi pengawasan yang dilakukan oleh OJK, maka perlu diterapkan juga Prinsip Keterbukaan Informasi.

Adapun mekanisme pengawasan yang dilakukan oleh OJK adalah menggunakan sistem supervisory tools dan supervisory action meliputi berbagai pemeriksaan seperti transasksi efek, kepatuhan lembaga efek, kepatuhan pengelolaan investasi, kepatuhan emiten dan kepatuhan profesi dan lembaga penunjang hal ini telah dilakukan sejak tahun 2019 dalam rangka menjaga kepaercayaan investor yang berinvestasi di Pasar Modal. Sanksi yang dapat dikenakan terhadap praktek kecurangan yang terjadi di Pasar Modal adalah Sanksi Administratif sebagaimana yang terdapat di dalam Pasal 102 Undang-undang Nomor 8 Tahun 1995 Tentang Pasar Modal, Sanksi Pidana yang diatur di dalam Pasal 103 sampai Pasal 110 Undang-undang Nomor 8 Tahun 1995 Tentang Pasar Modal dan KUHP jika berkaitan dengan penipuan (Pasal 378 KHP) dan penggelapan (Pasal 372 KUHP) dan Sanksi Perdata yaitu ganti kerugian sebagaimana yang dimaksud di dalam Pasal 1365 KUH Perdata.

\section{Saran}

1. Dalam melaksanakan optimasi pengawasan, maka OJK dapat bekerjasama dengan pihak-pihak terkait termasuk aparat kepolisian dan organisasi profesi penunjang pasar modal.

2. Undang-undang No 21 Tahun 2011 Tentang OJK harus direvisi lagi guna mempertegas mekanisme pengawasan khususnya di Pasar Modal, selain itu revisi Undang-undang Nomor 8 Tahun 1995 Tentang Pasar Modal sangat diperlukan dalam rangka memperkuat sanksi hukum dalam rangka penegakan hukum di Pasar Modal.

\section{DAFTAR PUSTAKA}

Anwar Jusuf. (2008). Penegakan Hukum Dan Pengawasan Pasar Modal. Bandung: PT. Alumni Bandung Fadjar Abdul Mukthie. (2016). Sejarah, Elemen dan Tipe Negara Hukum. Malang: Setara Press

Haryani Iswi dan R. Serfianto. (2010). Buku Pintar Hukum Bisnis Pasar Modal (Strategi Tepat Investasi Saham, Obligasi, Waran, Right, Opsi, Reksadana \& Produk Pasar Modal Syariah. Jakarta: Visimedia Nasarudin M. Irsan dan Indra Surya. (2004). Aspek Hukum Pasar Modal Indonesia. Jakarta: Prenada Media Raharjo Satjipto. (2016_. Hukum Progresif Sebuah Sintesa Hukum Indonesia. Yogyakarta: Genta Publishing Sutedi Adrian. (2009). Segi-Segi Hukum Pasar Modal. Bogor: Ghalia Indonesia.

Soekanto, Soerjono. (2005). Faktor-Faktor Yang Mempengaruhi Penagkan Hukum. Jakarta: PT. RajaGrafindo Persada

Syamsuddin Rahman. (2019). Pengantar Hukum Indonesia. Jakarta: Prenadamedia Group https://yuokysurinda.wordpress.com/2016/02/27/teori-hukum-pembangunan-mochtar-kusumaatmadja diakses pada hari Senin Tanggal 2 November 2020 Jam 18.05 Wita

https://native.kontan.co.id/news/ojk-perketat-pengawasan-pasar-modal-tingkatkan-kepercayaan-investor diakses pada hari Selasa Tanggal 11 November 2020 Jam 14.48 Wita

https://market.bisnis.com/read/20190815/7/1136922/tindak-tegas-pelanggaran-di-pasar-modal-pengamatapresiasi-ojk-dan-bei yang diakses Pada hari Minggu Tanggal 15 November 2020 Jam 10.38 Wita https://blogmhariyanto.blogspot.com/2009/09/penegakan-hukum-pelaku-tindak-pidana.html yang diakses Pada hari Minggu Tanggal 15 November 2020 Jam 11.01 Wita 